\title{
Tsunami Deposit Study Using 2D ERI Technique in Thoothukudi Shoreline, Tamil Nadu, India
}

\author{
A. Antony Ravindran \\ Department of Geology and Geophysics Research Lab, \\ Manonmaniam Sundaranar University, Thoothukudi, India
}

\begin{abstract}
The aim of the study is about beaches in the study area acts like a sponge but the groundwater along the beach is very dynamic. The flow direction of the beach groundwater is mainly governed by the physical and geological characteristics of the beaches as well as the waves and tide conditions in the sea. The Indian Ocean Tsunami 2004 was affected and sediment deposited in the Thoothukudi shoreline. Through the 2D Electrical Resistivity Imaging (ERI) Technique, an attempt is made to understand the interface zone of the seawater intrusion and the land groundwater along the beach groundwater table and Tsunami deposits in the Thoothukudi shoreline. The profiles survey were carried out using the help of equipment like CRM-500, Multicore cable, electrodes and Res 2DINV Software. The measuring profiles are predetermined as a interval of electrodes in $\mathrm{m}$ and $\mathrm{cm}$ scales. From four profiles study is to determine the salt water and clay tsunami deposit range of apparent resistivity from $1-5 \Omega \mathrm{m}^{-1}$, sandy $10-100 \Omega \mathrm{m}^{-1}$.
\end{abstract}

Key words: Tsunami, sediments, 2D ERI, Thoothukudi shoreline, resistivity, India

\section{INTRODUCTION}

The Tsunamigenic earthquake of December 26th, 2004 happened on the interface of the India and Burma plates and was caused by the release of stresses that develop as the Indian plate subducts beneath the overriding Purma plate. The coastal area of Gulf of mannar region was affected due to tsunami. The geological and for paleoseismological approach in search of ancient tsunami deposits and geomorphic features which were the direct diagnostic criteria of the ancient earthquake (Keating et al., 2004). Geo-electrical studies for delineating ground-water contamination due to salt-water intrusion in the delta (Ebraheem et al., 1997; Zohdy et al., 1993). Tsunamis have the potential to deposit sand farther inland or at a higher elevation than storms (Dawson and

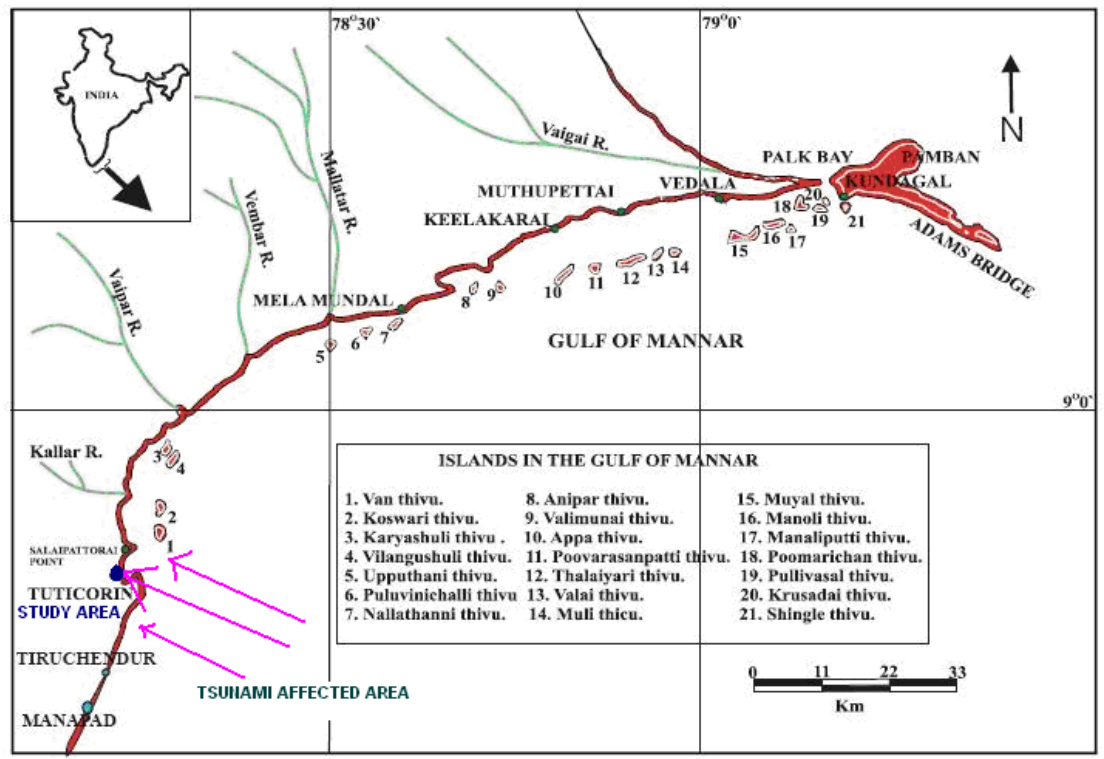

Fig. 1: Location map of the study area 
Shi, 2000; Dawson et al., 1988). The use of 2 D resistivity imaging (electric tomography) identifies the tsunami deposits in the Thoothukudi shoreline (Fig. 1) Thoothukudi district, located along South-East of India. This is one of Pearl city of India and Coastal district of Tamil Nadu state. This is located between $8^{\circ} 19^{\prime}$ and $9^{\circ} 20^{\prime} \mathrm{N}$ latitudes and $77^{\circ} 40^{\prime}$ and $78^{\circ} 10^{\prime} \mathrm{E}$ longitudes. It has a semi arid-tropical climate.

Air temperature data indicate that May to August are the hottest months in district and December to February are coolest months in every year. The mean annual temperature of district is $28.3^{\circ} \mathrm{C}$. Mean annual precipitation of rainfall is $675.71 \mathrm{~mm}$. Major rainfall is received during the Northeast monsoon period. Maximum rainfall is in month of November.

Geology of the study area: The archean formation of Thoothukudi district include quartzite, garnetiferous biotite gneiss, charnockite, calc granulite and pink granite. The general trend of the Quartzite is NS to NE-SW with gently dipping towards East to Southeast. A group of fine grained marine calcareous sandstone and limestone and gritty sandstone intercalated with pebble bed probably referable to mio-pliocene age lie over the archeans. Dunes of white sand and red Teri sands of recent origin parallel to the coast are found (Ravindran et al., 2011). Since Thoothukudi is one of the important coastal district of Tamil Nadu state. The coastal features are occurring such as bays, lagoons, estuaries, cliffs, dunes, backshore width, beach width, wave cut features etc.

\section{MATERIALS AND METHODS}

The tsunamigenic deposits were studied using the 2D electrical resistivity imaging study to parallel to shoreline. It is one of the powerful tools to identify sedimentary deposits of the study area. The 2D Electrical Resistivity Imaging Technique is a fast and cost effective technique which covers both vertical and horizontal changes in the surface and the subsurface of the geological formations of the study area.

To determine the true subsurface resistivity, the collected resistivity data are inverted into apparent resistivity data by using Res $2 \mathrm{D}$ INV Ver.3.56 software and iterated to calculate a resistivity model section (Ravindran, 2010; Ravindran and Ramanujam, 2012). This approach minimizes the difference between the observed data and the calculated apparent resistivity values. The data were collected using the equipment of Aquameter CRM 500, 48 steel electrodes, 12 Volts battery,

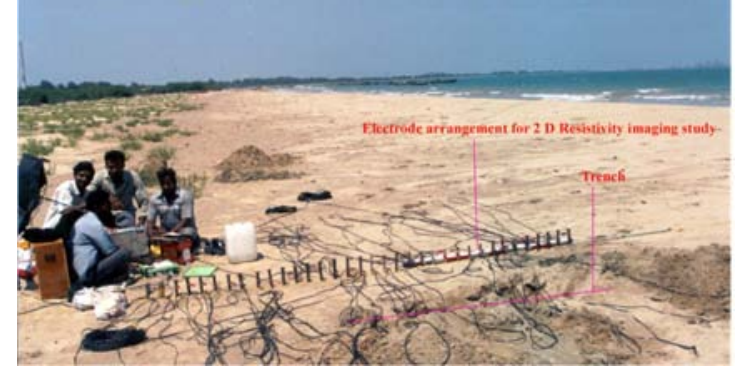

Fig. 2: Tsunamigenic deposits field work data collection using 2D ERI electrode arrangement and open trench technique

multi core cables to a length of $240 \mathrm{~m}$ and manually operated switching unit have been used for the data collection. Wenner electrode configuration has been used for $2 \mathrm{D}$ electrical resistivity imaging studies. Lateral extension of the spaces can be made by roll on technique. To find out the layer thickness of $10 \mathrm{~cm}$ tsunami deposits, $20 \mathrm{~cm}$ electrode spacing should be adopted in Wenner configuration.

The tsunami deposit identified at a depth of $80 \mathrm{~cm}$ is having lower resistivity than the surrounding beach sands. In the preliminary study, it has been revealed that fine-grained deposits at the $80 \mathrm{~cm}$ depth are found more conductive than surrounding beach sands (Fig. 2).

\section{RESULTS AND DISCUSSION}

The profile 1 (Fig. 3) trends E-W direction to a length of $8 \mathrm{~m}$. The inversion pseudosection displays the range of resistivity values from $17 \Omega \mathrm{m}^{-1}$ indicating that sandstone upto a depth of $7.9 \mathrm{~m}$. The low resistivity zone of pseudosection with the range of resistivity is $0.04-0.51 \Omega \mathrm{m}^{-1}$ at a depth of $3.7-7.9 \mathrm{~cm}$ indicating the tsunamicgenic deposits of the study area.

The profile 2 (Fig. 4) trends SE to NW direction to a length of $100 \mathrm{~m}$. The range of low resistivity zone with 1-5 $\Omega \mathrm{m}^{-1}$, from the surface of the profile to a depth of $3.8 \mathrm{~m}$ indicates a saltwater and tsunami sediment deposited area. The high resistivity values starting from 5-10 $\Omega \mathrm{m}^{-1}$ extending further downwards upto a depth of $11.9 \mathrm{~m}$ in the pseudosection exhibits the distribution of sand and sand dunes of the study area.

The profile 3 (Fig. 5) trends NE to SW direction at a length of $100 \mathrm{~m}$. The tsunami sediment at top of pseudosection are identified with resitivity values from $10.8-5 \Omega \mathrm{m}^{-1}$ at a depth of $5.6 \mathrm{~m}$. The sand and sandstone is recognized from the depth of $3.8 \mathrm{~m}$ to a depth $11.9 \mathrm{~m}$ in 


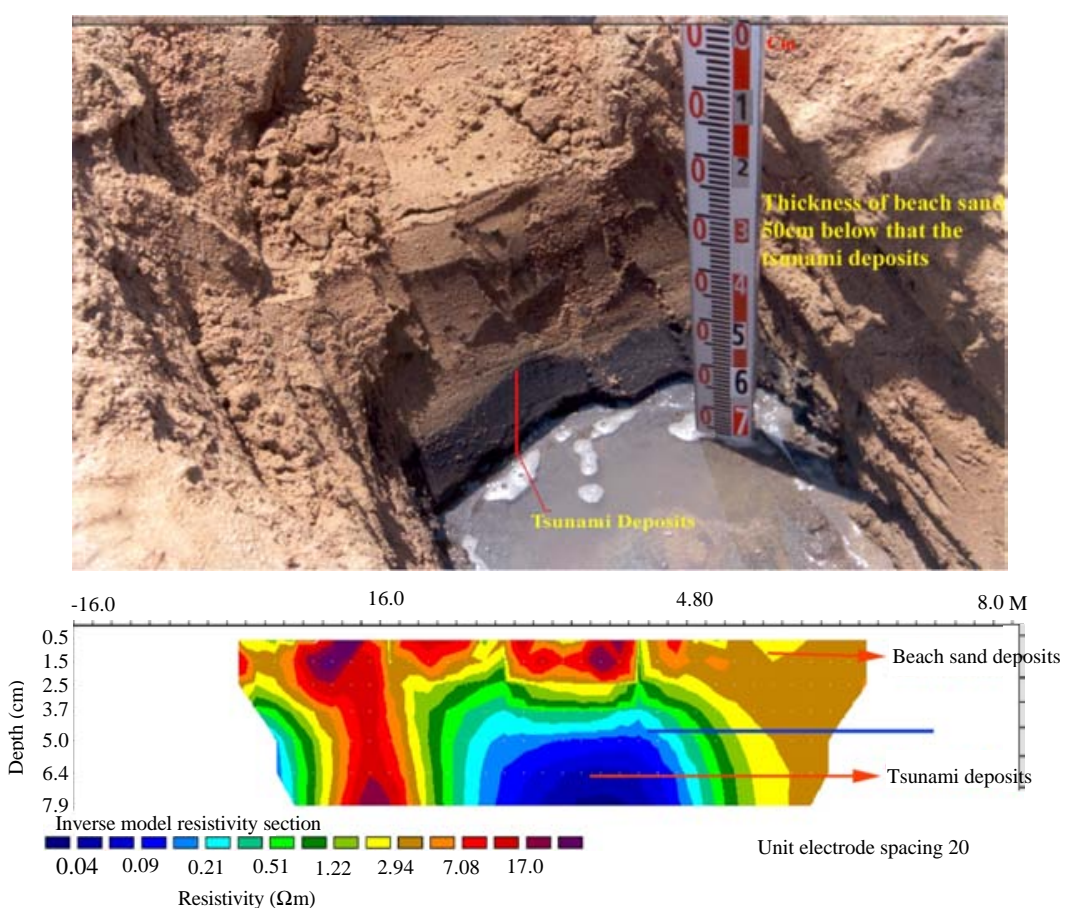

Fig. 3: 2D electrical resistivity imaging pseudosection depicts the distribution of beach sediments and sand dunes in coastal zone of Thoothukudi shoreline profile 1

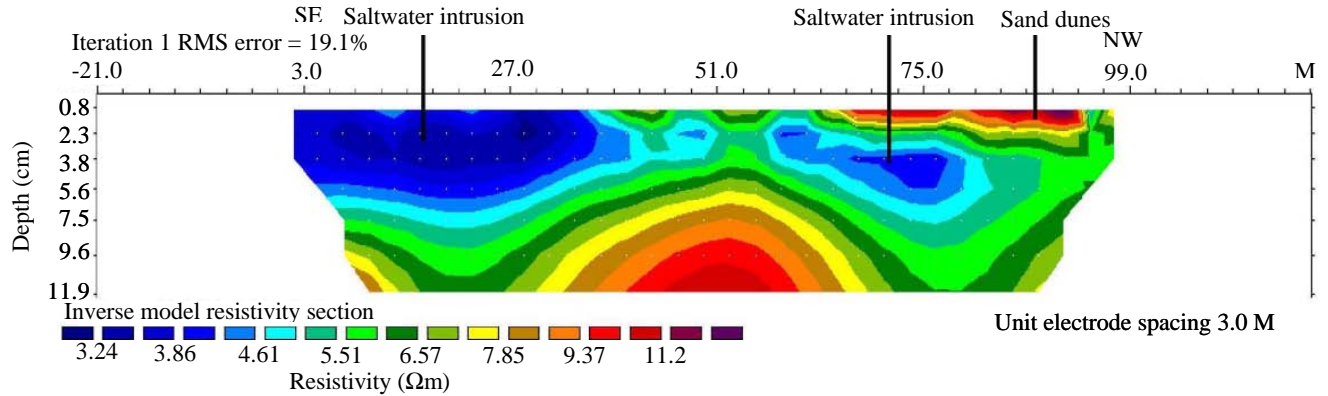

Fig. 4: $2 \mathrm{D}$ electrical resistivity imaging pseudosection depicts the distribution of beach sediments and sand dunes in coastal zone of Thoothukudi shoreline profile 2

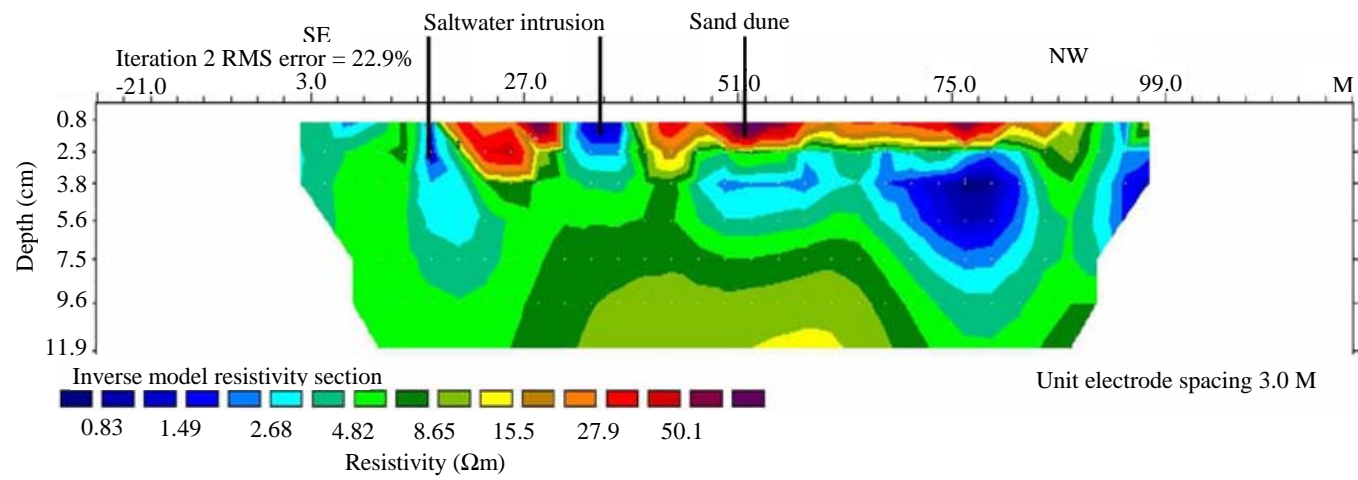

Fig. 5: 2D electrical resistivity imaging pseudosection depicts the distribution of beach sediments and sand dunes in coastal zone of Thoothukudi shoreline profile 3 
OnLine J. Earth Sci., 5 (3-6): 22-25, 2011

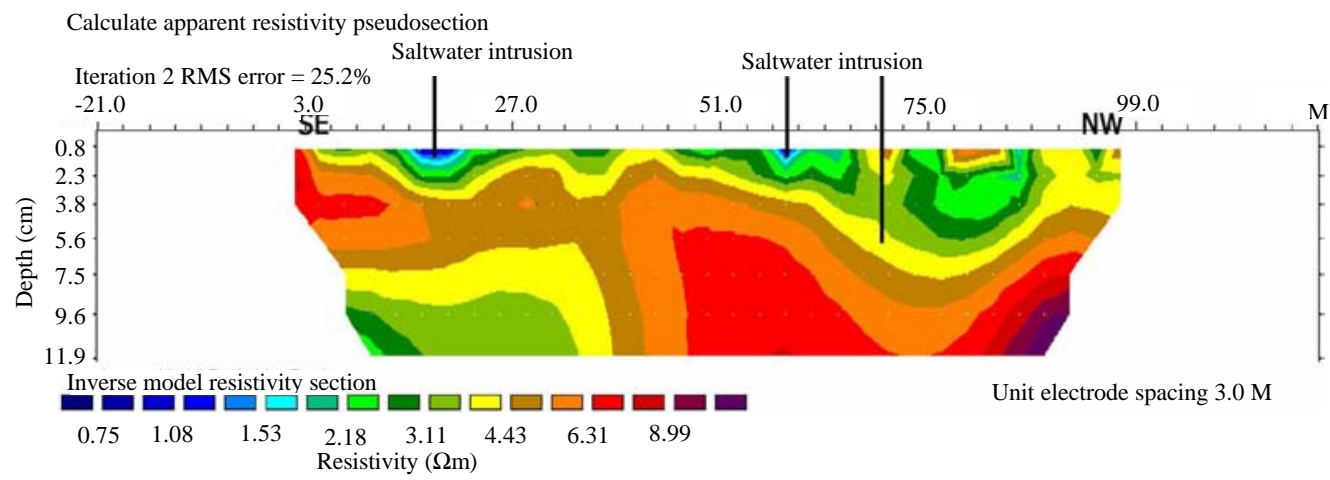

Fig. 6: 2D electrical resistivity imaging pseudosection depicts the distribution of beach sediments and sand dunes in coastal zone of Thoothukudi shoreline profile 4

the pseudosection with the range of resistivity values of 5-10 $\Omega \mathrm{m}^{-1}$. The profile 4 (Fig. 6) trends SE to NW direction to a length of $100 \mathrm{~m}$ distance. The sedimentary rock formation of sand, sandstone is demarcated with the range of resistivity from $5-9 \Omega \mathrm{m}^{-1}$. The Tsunami sediments and saltwater intrusion is identified with the range of resistivity value from $1-3 \Omega \mathrm{m}^{-1}$ at a depth of $11.9 \mathrm{~m}$

\section{CONCLUSION}

The 2D Electrical Resistviity Imaging Technique is used for identification of tsunamigenic deposits in the coastal region of thoothugudi shoreline. The four 2D profiles have been carried out to assess the subsurface geological and hydrogeological condition to a depth about $11.9 \mathrm{~m}$. 2D pseudosection were constructed for each sites and they show a zones of high resistivity between 5 and $10 \Omega \mathrm{m}^{-1}$ which is encircled by a sandstone and sand in dry conditons. The low resistivity zone falls below the $0.8-5 \Omega \mathrm{m}^{-1}$ which indicates saltwater and tsunamigenic sediments upto a depth of $5 \mathrm{~m}$ from subsurface.

The pseudosections plotted from the data obtained for the study area reveal the saltwater movement of salinity structures due to tsunamigenic earthquake in Indian ocean. The study based on the constructed 2D pseudosection profiles a perfect subsurface tsunami sediments and flow movements of the groundwater were established compared with trenching data at Thoothukudi shoreline, Tamil Nadu, India.

\section{ACKNOWLEDGEMENTS}

Researchers express their sincere thanks to $\mathrm{Mr}$. A.P.C.V. Chockalingam, Secretary and Prof. Maragathasundaram, Principal, V.O.C. College, Tuticorin. The helps extended by Dr. N. Ramanujam, Professor and Head, Coastal Disaster Management, Pondicherry University, Andaman.

\section{REFERENCES}

Dawson, A.G. and S.Z. Shi, 2000. Tsunami deposits. Pure Applied Geophys., 157: 875-897.

Dawson, A.G., D. Long and D.E. Smith, 1988. The storegga slides: Evidence from Eastern Scotland for a possible tsunami. Mar. Geol., 82: 271-276.

Ebraheem, A.A.M., M.M. Senosy and K.A. Dahab, 1997. Geoelectrical and hydrogeochemical studies for delineating ground-water contamination due to saltwater intrusion in the Northern part of the Nile Delta, Egypt. Ground Water, 35: 216-222.

Keating, B., F. Whealan and J. Balley-Brock, 2004. Tsunami deposits at Queen's beach, Oahu, Hawaii: Initial results and wave modeling. Sci. Tsunami Hazards, 22: 23-43.

Ravindran, A. and N. Ramanujam, 2012. A case study of crystalline limestone intrusion and fault zone identication using 2D ERI technique in Ramco cements, pandalgudi mines, Tamilnadu. Int. Res. J. Geol. Mining, 2: 11-15.

Ravindran, A. and N. Ramanujam, G. Manimaran and D. Manimaran, 2011. Exploration of freshwater movement in Palaeo river and coastal environmental study using 2D ERI study in zirconium complex, atomic energy, Pazhayakayal, Thoothukudi. Res. J. Earth Sci., 3: 57-62.

Ravindran, A., 2010. Characterization of the geology of subsurface shallow conglomerate using 2D electrical resistivity imaging at Baragadi, Panna district, Madhya Pradesh, India. J. Applied Sci. Environ. Manage., 14: 33-36.

Zohdy, A.A.R., P. Martin and R.J. Bisdorf, 1993. A study of seawater intrusion using direct-current soundings in the Southeastern part of the Oxnard Plain, California. Open-File Report 93-524, U.S. Department of the Interior, U.S. Geological Survey, pp: 1-139. http://pubs.usgs.gov/of/1993/0524/report.pdf. 